\title{
Analysis of Somaclonal Variation in Natural Tetraploid Trifolium pratense L. Regenerants Using RAPD Markers
}

\author{
Yeşim KORKMAZ KASAP', Hatice ÇÖLGEÇEN², Havva ATAR ${ }^{2 *}$ \\ ${ }^{1}$ Department of Biology, Graduate School of Science Engineering and Technology, Zonguldak, Turkey \\ ${ }^{2}$ Department of Biology, Faculty of Arts and Science, Zonguldak Bülent Ecevit University, Zonguldak, Turkey \\ ORCID ID: Yeşim KORKMAZ KASAP: https:/ / orcid.org/0000-0002-0950-7890; Hatice ÇÖLGEÇEN: https:// orcid.org/0000-0001-8246-4279; \\ Havva ATAR: https://orcid.org/0000-0003-0518-6265
}

\begin{tabular}{|c|c|c|}
\hline Received: 18.03.2019 & Published online: 30.06 .2019 & Issue published: 30.06 \\
\hline \multicolumn{3}{|c|}{$\begin{array}{l}\text { Abstract: Trifolium pratense L. is an agricultural legume which is grown mainly in Europe, North America, and Anatolia. As } \\
\text { the plant shows great diversity in Anatolia, Anatolia was accepted as the center of the origin of T. pratense L. This study aimed } \\
\text { to analyze somaclonal variation among natural tetraploid T. pratense L. regenerants propagated in vitro and their donor plants } \\
\text { by using RAPD techniques. In this study, for regeneration, the apical meristems of aseptic plants germinated on hormone-free } \\
\text { MS medium were used, then they were transfered on PC - L } 2 \text { medium containing } 1 \mathrm{mg} / 1 \mathrm{NAA}+3 \mathrm{mg} / 1 \mathrm{BAP} \text {. In this research, } \\
\text { RAPD techniques including } 8 \text { different primers were used to detect somaclonal variation. As a result, all of the primers showed } \\
\text { polymorphism. The lowest polymorphism percentage was seen between number } 2 \text { clone and donor with } 17.07 \%\left(\mathrm{D}_{2}-\mathrm{C}_{2}\right) \text {, the } \\
\text { highest polymorphism percentage was seen between number } 4 \text { clone and donor with } 60.21 \%\left(\mathrm{D}_{4}-\mathrm{C}_{4}\right) \text {. The highest variation } \\
\text { difference was seen between donors D2 (a total of } 123 \text { bands) and D6 (total } 86 \text { bands). }\end{array}$} \\
\hline
\end{tabular}

Keywords: Trifolium pratense L., plant regeneration, somaclonal variation.

\section{Doğal Tetraploid Trifolium pratense L. Rejenerantlarında RAPD Markırları Kullanılarak Somaklonal Varyasyonun Belirlenmesi}

Öz: Trifolium pratense L., Avrupa, Kuzey Amerika, Anadolu'da yaygın olan yetişen tarımsal bir baklagildir. T. pratense L. Anadolu'da büyük çeşitlilik gösterdiği için Anadolu köken merkezi olarak kabul edilmiştir. Bu çalışma, in vitroda üretilen doğal tetraploid T. pratense L. rejeneratları ve donör bitkileri arasındaki somaklonal değişimi RAPD tekniklerini kullanarak analiz etmeyi amaçlamıştır. Bu çalışmada, $1 \mathrm{mg} / 1 \mathrm{NAA}+3 \mathrm{mg} / 1$ BAP içeren PC - L2 besiyerine bitki büyüme düzenleyicisi içermeyen MS ortamında çimlendirilen aseptik bitkilerin apikal meristemleri ekilerek rejenerasyon yapılmıştır. Bu araştırmada, somaklonal varyasyonu saptamak için 8 farklı primer kullanılarak RAPD tekniği uygulanmıştır. Primerlerin tümü polimorfizm göstermiştir. En düşük polimorfizm yüzdesi, \% 17.07 (D2-C2) ile 2 numaralı klon ve donör arasında görülmüş, en yüksek polimorfizm yüzdesi \% 60.21 (D4-C4) ile 4 numaralı klon arasında görülmüştür. En yüksek varyasyon fark1 donör D2 (toplam 123 bant) ve D6 (toplam 86 bant) arasında görülmüştür.

Anahtar kelimeler: Trifolium pratense L., bitki rejenerasyonu, somaklonal varyasyon.

\section{Introduction}

The variation among plants regenerated from an in vitro culture is termed somaclonal variation. Such variations resulted by the alterations in genetic structures of the plants regenerated from in vitro culture are heritable and therefore persist over generations. Typical genetic alterations are: changes in chromosome numbers, chromosome structure and gene DNA sequence.

Estrogen deficiency in the body leads to such symptoms of decreased bone density, hot flashes, sweats, unrest, tingling in arms and legs, difficulty falling asleep, headache, nervousness, muscle and joint aches. Phytoestrogens which mimic mammalian estrogen and its biological activities are widely used in treatment of menopausal symptoms. Phytoestrogens are reported to prevent cancer, heart diseases and osteoporosis. Trifolium pratense L. has a rich content of isoflavonoids which are known to have estrogenic effect (Çölgeçen, Koca, \& Büyükkartal, 2011). The natural tetraploid T. pratense has a seed setting problem which inhibits reproduction.
Regeneration is considered as an alternative method for resolution of reproduction problem (Algan \& Büyükkartal, 1999; Çölgeçen \& Toker, 2008). This study aimed to analyze somaclonal variation among natural tetraploid $T$. pratense regenerants propagated in vitro and their donor plants by using Randomly Amplified Polymorphic DNA (RAPD) techniques.

\section{Material and Methods}

\subsection{Plant material}

Natural tetraploid T. pratense E2 type, $2 n=4 x=28$ chromosomes, which is grown in the experimentation greenhouse of Bülent Ecevit University Faculty of Arts and Science was used in this study. It was used one individual for each donor and clone.

\subsection{Seed sterilization}

For surface sterilization, the seeds were treated with $10 \%$ sodium hypochlorite $(\mathrm{NaOCl})$ for $10 \mathrm{~min}$ and washed 3 times with distilled water. 


\subsection{Callus initiation and plant regeneration}

Hormone-free Murashige and Skoog (MS) medium was used for seed germination. Aseptic seedlings were grown to be used as explant sources. The age of the plant tissue effects DNA quality and quantity. It is difficult to purify DNA from mature tree leaves because of their thick cell wall and high content of polysaccharides and phenolic compounds. Due to this fact, young aseptic seedlings were used in this study.

Apical meristem $(1 \mathrm{~mm})$ of the 15-day-old aseptic seedlings was used as explant source (Fig. 1). The most successful PC-L2 medium supplemented with $1 \mathrm{mg} / 1$ $\mathrm{NAA}+3 \mathrm{mg} / \mathrm{l} \mathrm{BAP}$ was used for plant regeneration (Çölgeçen et al., 2008).

\subsection{DNA extraction}

Genomic DNA isolation from natural tetraploid T. pratense donor and clone plant samples were performed using the protocol of Lefort, Lally, Thompon, and Douglas (1998). DNA isolation from Trifolium was performed by using modified CTAB method. Because of the fact that the phenolic compounds cause contamination, young aseptic seedlings were used in this study and DNA isolation was performed using the protocol of Lefort et al. (1998). The quality and quantity of the isolated DNAs were determined by a nanodrop. In DNA quality assessment, high-quality DNAs will have an A260/A280 ratio of 1.8-2.0. An A260/A280 value above 2.0 indicates contamination with RNA, chloroform or phenol and A260/A280 value below 1.8 indicatesprotein or phenolic content in DNA. DNA purity ratios calculated in this study ranged between 1.49-2.07. The quantity and purity of the obtained genomic DNA were measured by a nanodrop.

2.5. Randomly Amplified Polymorphic DNA (RAPD) analysis:

RAPD-PCR method of Williams, Kubelik, Livak, Rafalski, and Tingey (1990) was used in the study. 8 primers were used, the codes and sequences of which are specified below in Table 1. It was used: $20 \mathrm{ng}$ genomic DNA, 10X reaction buffer, $2.5 \mathrm{mM} \mathrm{MgCl}_{2}, 20 \mu \mathrm{M}$ dNTPs, $0.2 \mu \mathrm{M}$ primer, 0,5 unit Taq polymerase.

PCR cycling conditions:

$95^{\circ} \mathrm{C} 2 \mathrm{~min}$,

$\left.\begin{array}{l}94^{\circ} \mathrm{C} 30 \mathrm{sec} \\ 36^{\circ} \mathrm{C} 1,5 \mathrm{~min} \\ 72^{\circ} \mathrm{C} 1,5 \mathrm{~min}\end{array}\right\} 40$ cycles

$72^{\circ} \mathrm{C} 5 \mathrm{~min}$

The bands obtained by RAPD-PCR were analyzed by $1.6 \%$ agarose gel electrophoresis.

Table 1: Information regarding primer codes and sequences

\begin{tabular}{ll}
\hline Primer & Nucleotide sequence $\left(\mathbf{5}^{\prime} \rightarrow \mathbf{3}^{\prime}\right)$ \\
\hline OPC 01 & TTCGAGCCAG \\
OPC 02 & GTGAGGCGTC \\
OPC 05 & GATGACCGCC \\
OPC 06 & GAACGGACTC \\
OPC 08 & TGGACCGGTG \\
OPC 09 & CTCACCGTCC \\
OPO 07 & CAGCACTGAC \\
TUBE A08 & GTGACGTAGG \\
\hline
\end{tabular}

\subsection{Statistics}

Genomic template stability (GTS) is a quantitative measure reflecting the changes in the number of RAPD profiles. The changes in the number of RAPD profiles indicate the changes of percentage of GTS. Polymorphism in RAPD profiles represents the proportion of the number of bands lost and newly produced in comparison to the control over the total number of bands in control.

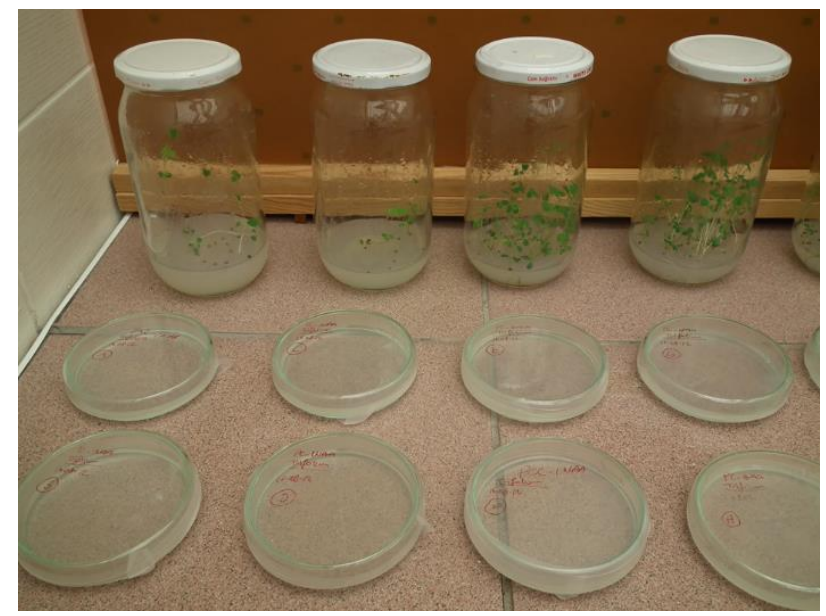

Figure 1: The production of regenerant plants from aseptic seedling.

\section{Results}

Polymorphism calculations were performed by comparing the band profiles of samples and the control for each primer. The bands which were present in the control but missing in the sample and the bands which did not exist in control and newly appeared in the samples were evaluated as polymorphism. Polymorphism percentages were calculated as the proportion of polymorphic bands over the total number of bands. $6 \mathrm{~T}$. pratense L. aseptic donor plants and 6 clone plants were used in the study. Donor plants were represented by $\mathrm{D}$, clone plants were represented by $\mathrm{C}$ and a total of 8 primers OPC $01, \mathrm{OPC} 02$, OPC 05, OPC 06, OPC 08, OPC 09, OPO 07 and Tube A08 were used for RAPD analyses.

In donor sample D1, primer OPC 01 produced 14 bands, primer OPC 02 produced 17 bands, primer OPC 05 produced 11 bands, primer OPC 06 produced 14 bands, primer OPC 08 produced 14 bands, primer OPC 09 produced 11 bands, primer OPO 07 produced 14 bands and primer Tube A08 produced 20 bands, all amounting to a total band number of 115 . In clone sample $\mathrm{C} 1$, in primer OPC 01, 4 news bands were produced and 2 bands were lost in comparison to the donor. In primer OPC 02, 3 news bands were produced and 1 band was lost in comparison to the donor. In primer OPC 05, 3 news bands were produced and 2 bands were lost in comparison to the donor. In primer OPC 06, 1 new band was produced and 3 bands were lost in comparison to the donor. In primer OPC 08 , no new or missing bands were recorded in comparison to the donor. In primer OPC 09, 4 new bands were produced and 3 bands were lost in comparison to the donor. In primer OPC 07, 4 new bands were produced and 5 bands were lost in comparison to the donor. In primer Tube 08, no newor missing bands were recorded in comparison to the donor. The polymorphism percentage between donor D1 and clone C1 was $30.43 \%$ (Table 2). 
In donor sample $\mathrm{D} 2$, primer OPC 01 produced 16 bands, primer OPC 02 produced 12 bands, primer OPC 05 produced 14 bands, primer OPC 06 produced 15 bands, primer OPC 08 produced 14 bands, primer OPC 09 produced 10 bands, primer OPO 07 produced 20 bands and primer Tube A08 produced 22 bands, all amounting to a total band number of 123 . In clone sample $\mathrm{C} 2$, in primer OPC 01,1 new band was produced in comparison to the donor and no missing bands were recorded. In primer OPC 02,12 new bands were produced in comparison to the donor and no missing bands were recorded. In primer OPC 05,14 new bands were produced in comparison to the donor and no missing bands were recorded. In primer
OPC 06,15 new bands were produced in comparison to the donor and no missing bands were recorded. In primer OPC 08,14 new bands were produced in comparison to the donor and no missing bands were recorded. In primer OPC 09, 10 new bands were produced and 3 bands were lost in comparison to the donor. In primer OPO 07, 20 new bands were produced and 5 bands were lost in comparison to the donor. In primer Tube A08, 22 new bands were produced in comparison to the donor and no missing bands were recorded. The polymorphism percentage between donor D2 and clone C2 was 17.07\% (Table 2).

Table 2: BAND modifications between donor and controls

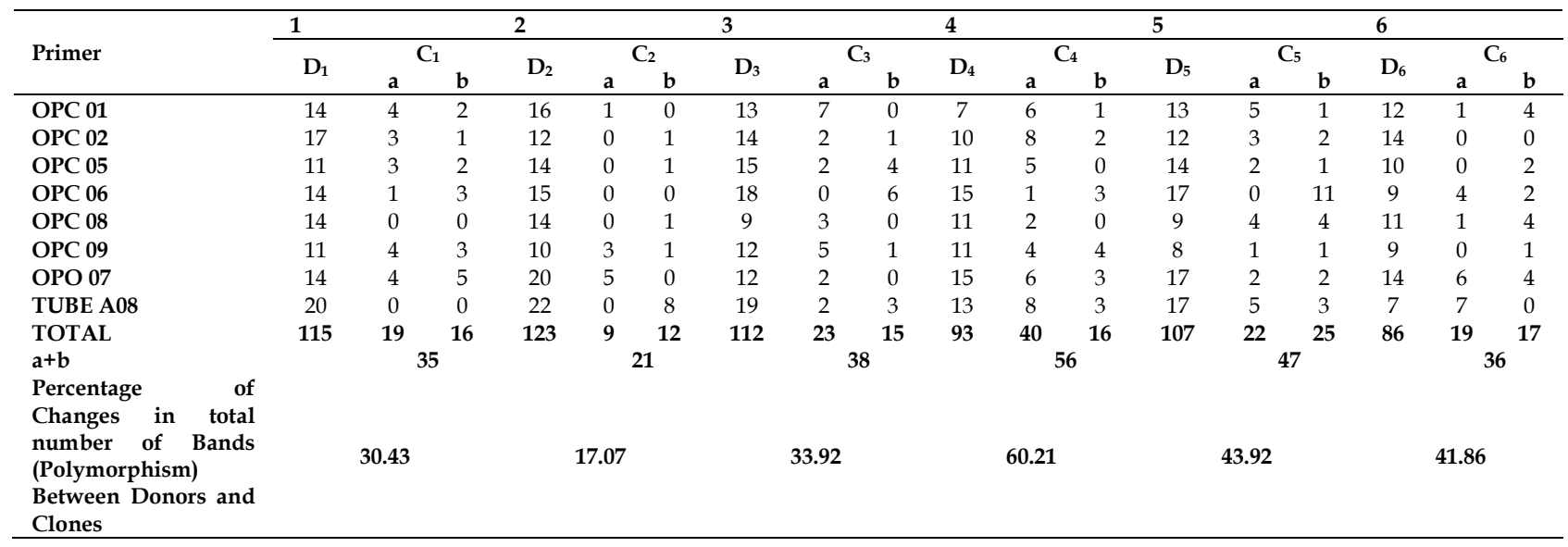

a: The number of newly produced bands in comparison to control ( $\mathrm{D}=$ Donor), b:The number of missing bands in comparison to control (D=Donor).

In donor sample D3, primer OPC 01 produced 13 bands, primer OPC 02 produced 14 bands, primer OPC 05 produced 15 bands, primer OPC 06 produced 18 bands, primer OPC 08 produced 9 bands, primer OPC 09 produced 12 bands, primer OPO 07 produced 12 bands and primer Tube A08 produced 19 bands, all amounting to a total band number of 112 . In clone C3, in primer OPC 01 , 7 new bands were produced in comparison to the donor and no missing bands were recorded. In primer OPC 02, 2 new bands were produced and 1 band was lost in comparison to the donor. In primer OPC 05, 2 new bands were produced and 4 bands were lost in comparison to the donor. In primer OPC 06, no new bands were produced and 6 bands were lost in comparison to the donor. In primer OPC 08, 3 new bands were produced in comparison to the donor and no missing bands were recorded. In primer OPC 09, 5 new bands were produced and 1 band was lost in comparison to the donor. In primer OPO 07, 2 new bands were produced in comparison to the donor and no missing bands were recorded. In primer Tube A08, 2 new bands were produced and 3 bands were lost in comparison to the donor. The polymorphism percentage between donor D3 and clone C3 was 33.92\% (Table 2).

In donor sample $\mathrm{D} 4$, primer OPC 01 produced 7 bands, primer OPC 02 produced 10 bands, primer OPC 05 produced 11 bands, primer OPC 06 produced 15 bands, primer OPC 08 produced 11 bands, primer OPC 09 produced 11 bands, primer OPO 07 produced 15 bands and primer Tube A08 produced 13 bands, all amounting to a total band number of 93 . In clone sample $C 4$, in primer OPC 01, 6 new bands were produced and 1 band was lost in comparison to the donor. In primer OPC 02, 8 new bands were produced and 2 bands were lost in comparison to the donor. In primer OPC 05, 5 new bands were produced in comparison to the donor and no missing bands were recorded. In primer OPC 06, 1 new band was produced and 3 bands were lost in comparison to the donor. In primer OPC 08, 2 new bands were produced in comparison to the donor and no missing bands were recorded. In primer OPC 09, 4 new bands were produced and 4 bands were lost in comparison to the donor. In primer OPO 07, 6 new bands were produced and 3 bands were lost in comparison to the donor. In primer Tube A08, 8 new bands were produced and 3 bands were lost in comparison to the donor. The polymorphism percentage between donor D4 and clone C4 was 60.21\% (Table 2).

In donor sample D5, primer OPC 01 produced 13 bands, primer OPC 02 produced 12 bands, primer OPC 05 produced 14 bands, primer OPC 06 produced 17 bands, primer OPC 08 produced 9 bands, primer OPC 09 produced 8 bands, primer OPO 07 produced 17 bands and primer Tube A08 produced 17 bands, all amounting to a total band number of 107 . In clone sample $C 5$, in primer OPC 01, 5 new bands were produced and 1 band was lost in comparison to the donor. In primer OPC 02, 3 new bands were produced and 2 bands were lost in comparison to the donor. In primer OPC 05, 2 new bands were 
produced and 1 band was lost in comparison to the donor. In primer OPC 06, no new bands were recorded and 11 bands were lost in comparison to the donor. In primer OPC 08,4 new bands were produced and 4 bands were lost in comparison to the donor. Inprimer OPC 09, 1 new band was produced and 1 band was lost in comparison to the donor.In primer OPO 07, 2 new bands were produced and 2 bands were lost in comparison to the donor. In primer Tube A08, 5 new bands were produced and 3 bands were lost in comparison to the donor. The polymorphism percentage between donor D5 and clone C5 was $43.92 \%$ (Table 2).

In donor sample D6, primer OPC 01 produced 12 bands, primer OPC 02 produced 14 bands, primer OPC 05 produced 10 bands, primer OPC 06 produced 9 bands, primer OPC 08 produced 11 bands, primer OPC 09 produced 9 bands, primer OPO 07 produced 14 bands and primer Tube A08 produced 7 bands, all amounting to a total band number of 86 . In clone sample $\mathrm{C} 6$, in primer OPC 01, 1 new band was produced and 4 bands were lost in comparison to the donor. In primer OPC 02 , no new or missing bands were recorded in comparison to the donor. In primer OPC 05, no new bands were recorded and 2 bands were lost in comparison to the donor. In primer OPC 06, 4 new bands were produced and 2 bands were lost in comparison to the donor. In primer OPC 08,1 new band was produced and 4 bands were lost in comparison to the donor. In primer OPC 09, no new bands were recorded and 1 band was lost in comparison to the donor. In primer OPO 07, 6 new bands were produced and 4 bands were lost in comparison to the donor. In primer Tube A08, 7 new bands were produced in comparison to the donor and no missing bands were recorded. The polymorphism percentage between donor D6 and clone C6 was 41.86\% (Table 2).

The highest polymorphism percentage of $60.21 \%$ was calculated between donor D4 and clone C4, followed by $43.92 \%$ between donor D5 and clone C5, 41.86\% between donor D6 and clone C6, 33.92\% between donor D3 and clone C3, 30.43\% between donor D1 and clone C1 and $17.07 \%$ between donor D2 and clone C2, being the lowest (Table 2).

Figures 2, 3, 4, 5, 6, 7, 8 and 9 are showed the image on agarose gel of amplification products are created by OPC 01, OPC 02, OPC 05, OPC 06, OPC 08, OPC 09, OPO 07 and Tube A08.

\section{Discussion}

This study aimed to analyze somaclonal variation between natural tetraploid $T$. pratense $L$. regenerants and their donor plants based on RAPD DNA techniques. RAPD technique advantages are: provides quick results, also is cheap. It requires little work force, a small amount of low quality DNA is sufficient, polymorphism ratio is high, universal primer set, no radioactivity required (Aydın, 2004; Arslan, 2004; Filiz \& Koç, 2011; Kumar \& Gurusubramanian, 2011).

In the first phase of the study, aseptic seedlings were obtained by using the seeds of natural tetraploid T. pratense L. and regeneration studies were performed according to the method of Çölgeçen et al. (2008). Apical meristem was used as the explant source to obtain clone plants by tissue culture techniques. Regeneration process was successfully completed without any contamination.

A single band was observed when DNAs were isolated and run on an agarose gel. The display of a single band indicates the yield of an unbroken genomic DNA purified from RNA and cell secondary metabolites and preserving its helical structure (Karataş \& Ağaoğlu, 2006).

The genetic variations between natural tetraploid $T$. pratense regenerants propagated in vitro were determined by observing the varying DNA bands in the 8 RAPD primers (OPC-01, OPC-02, OPC-05, OPC-06, OPC-08, OPC-09, OPO-07 and Tube A08) used in this study. All primers displayed polymorphism in agreement with findings of the former research indicating polymorphism in the same primers used in different species of family Fabaceae (Hossain, Konisho, Minami, \& Nemoto, 2003; Patil, Sawardekar, Gokhale, Bhave, Sawant, Sawantdesai, Lipne, Sabale, \& Joshi, 2013). All primers used in the study displayed polymorphism with varying amplification strengths and band numbers. Such changes at the genetic level indicated the presence of somaclonal variation in the obtained aseptic seedlings. Kongkiatngam, Waterway, Coulman, and Fortin (1996) was determined genetic variation among cultivars of red clover (T. pratense L.). They used genomic DNA samples of 15 differet cultivar of T. pratense L. 55 were polymorphic was obtained all of 79 amplified products. Therefore, they identified relationships between cultivars.

The other similar study, Sheidai, Aminpoor, Noormohammadi, and Farahani, (2008) was determined somaclonal variation in banana (Musa acuminate L.) cultivar Valery. They studied 289 bands and determined all of 147 bands were polymorph (51.40\%). 18 primers were used, consequently, OPI-07 produced the highest number of bands (24) while primers OPH-16 produced the lowest number (5).

Khan, Ahmad, Adnan, and Khan (2014) was determined the effect of somaclonal variation on salt tolerans and glycoalkaloid content of potato tubers. They selected 38 regenerated plants. They used 20 RAPD primers and was detected somaclonal variation in only four primers: OPAA-01, OPAA-03, OPAA-05, OPA-08.

The main reason for the success of RAPD analysis which is widely used for molecular identification is the detection of high level of polymorphism that requires small amounts of DNA (Williams et al., 1990). In this study, different levels of variations were detected with RAPD analyses by using small amounts of DNA. Different polymorphism percentages were recorded in RAPD band profiles. The lowest polymorphism percentage $(17.07 \%)$ was seen between number 2 clone and donor $\left(D_{2}-C_{2}\right)$, the highest polymorphism percentage $(60.21 \%)$ was seen between number 4 clone and donor $\left(\mathrm{D}_{4}-\mathrm{C}_{4}\right)$. The highest variation difference was seen between donors D2 (a total of 123 bands) and D6 (total 86 bands). Different polymorphism percentages were also reported in the literature. In tomatoes, a percentage of similarity of above 95\% was reported between the regenerants and the donor plants (Soniya, Banerjee, \& Das, 2011). In Arabidopsis thaliana, polymorphism percentage was $66.6 \%$ among the regenerants derived from the same explant and $40 \%$ among the regenerants (Polanco \& Ruiz, 2002). 
Polymorphism percentage among Capsicum annuum regenerants ranged between $1.3 \%$ and $3.8 \%$ (Hossain, Konisho, Minami, \& Nemoto, 2003). In Vigna ungulculata, polymorphism percentage was calculated as $72.82 \%$ (Patil et al., 2013). High polymorphism percentages detected in this study might be attributed to ploidy-dependent somaclonal variation. Besides, the use of a natural tetraploid $T$. pratense as the study material might have increased the polymorphism percentage.

In conclusion, although regeneration studies were performed by using natural tetraploid T. pratense, there are not any studies in the literature on the analysis of somaclonal variation between the donors and the clones produced by tissue culture methods. In the present study, somaclonal variation percentages were determined in propagation of natural tetraploid of $T$. pratense, -which has seed setting problem- by tissue culture methods. After this stage, based on the known variation percentages, regenerants of this plant may be produced as appropriate to its usage as feed or medicinal plant. In case the individuals with high somaclonal variation display varying levels of secondary metabolites to be used as medicine raw materials, it may be possible to produce other types of regenerants. The findings of this thesis study will be useful for optimization of the utilization of natural tetraploid $T$. pratense in different usage areas including feeding and medicine. The propagation of the clones with low variation percentages will facilitate optimization processes.

Acknowledgements: This study was supported by Bulent Ecevit University Scientific Research Project (project no: 2012-10-06-14).

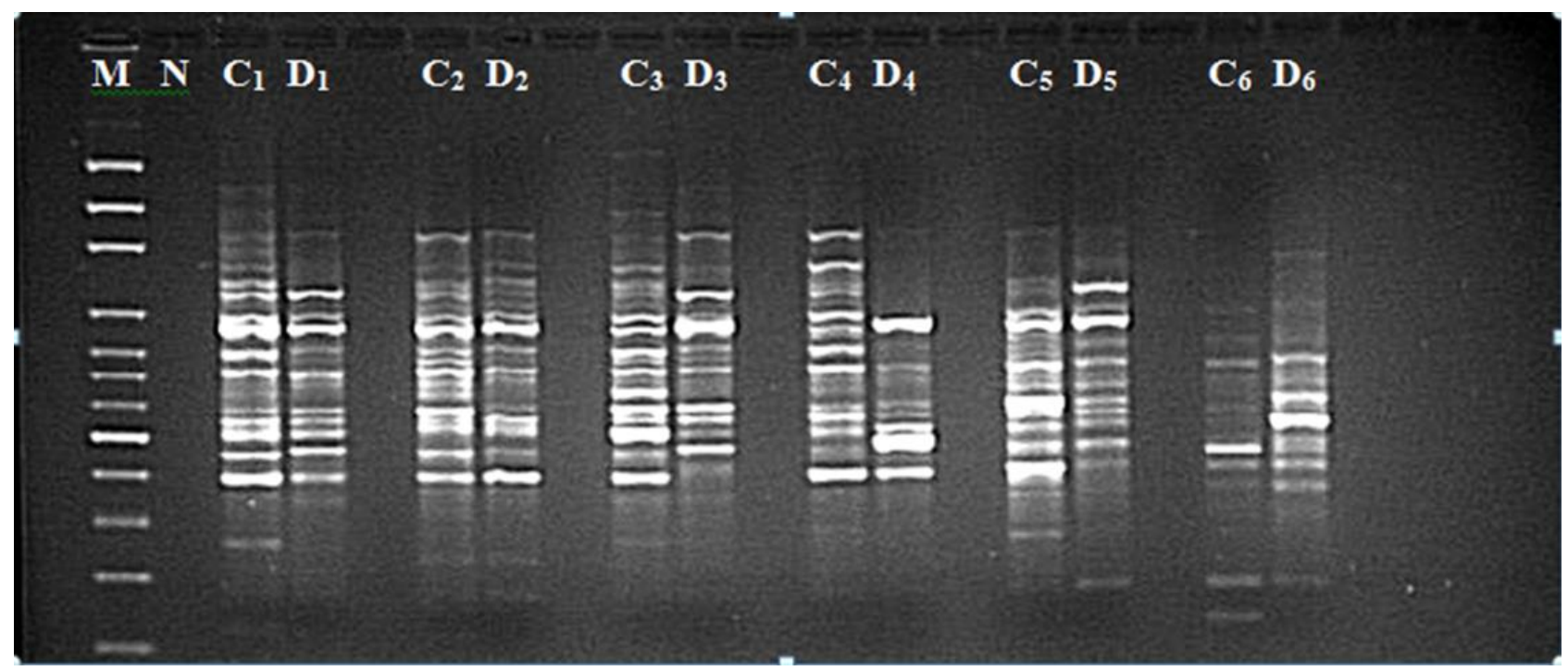

Figure 2: The image on agarose gel of amplification products are created by OPC 01 primer (M: marker, N: negative).

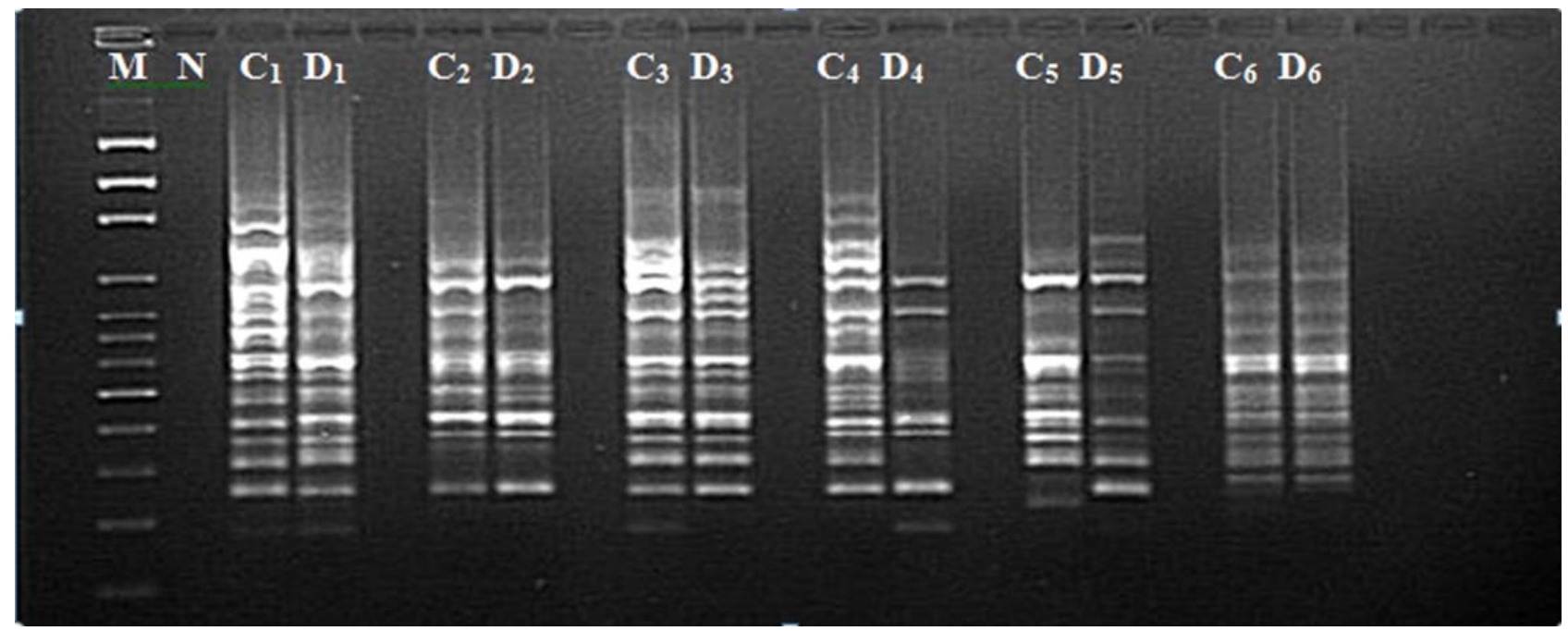

Figure 3: The image on agarose gel of amplification products are created by OPC 02 primer (M: marker, N: negative). 


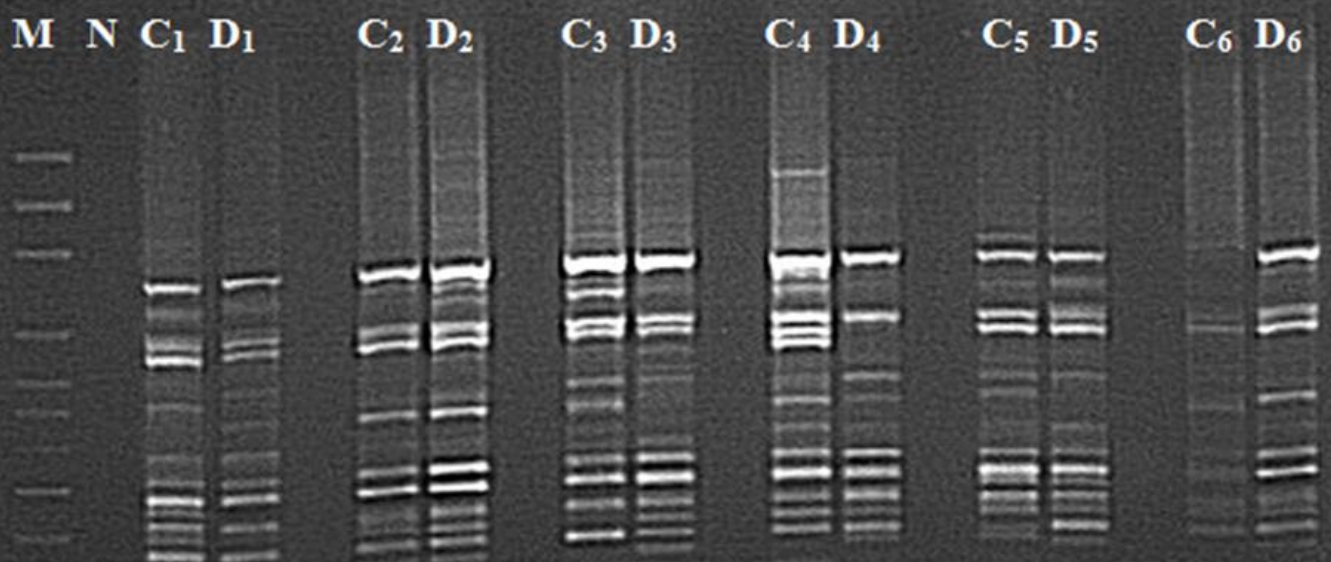

Figure 4: The image on agarose gel of amplification products are created by OPC 05 primer (M: marker, N: negative).

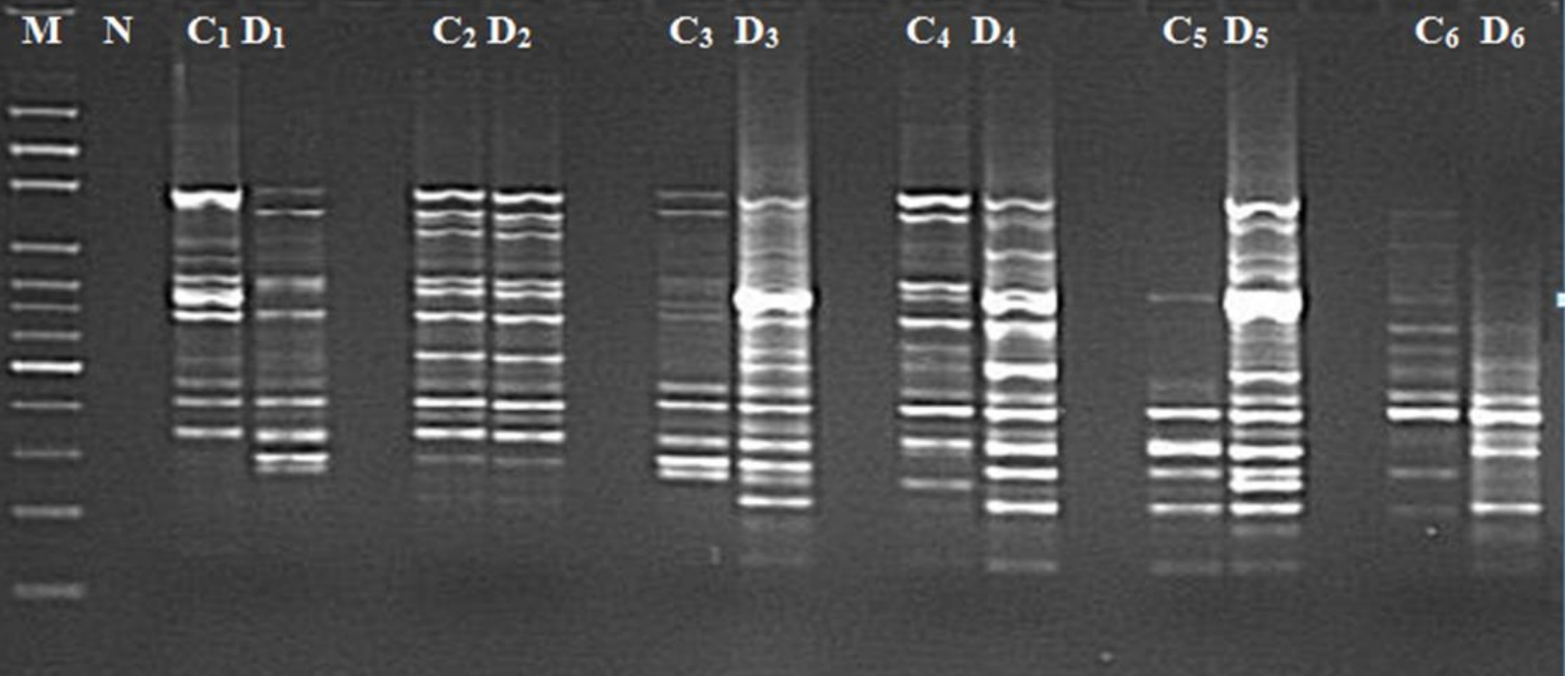

Figure 5: The image on agarose gel of amplification products are created by OPC 06 primer (M: marker, N: negative).

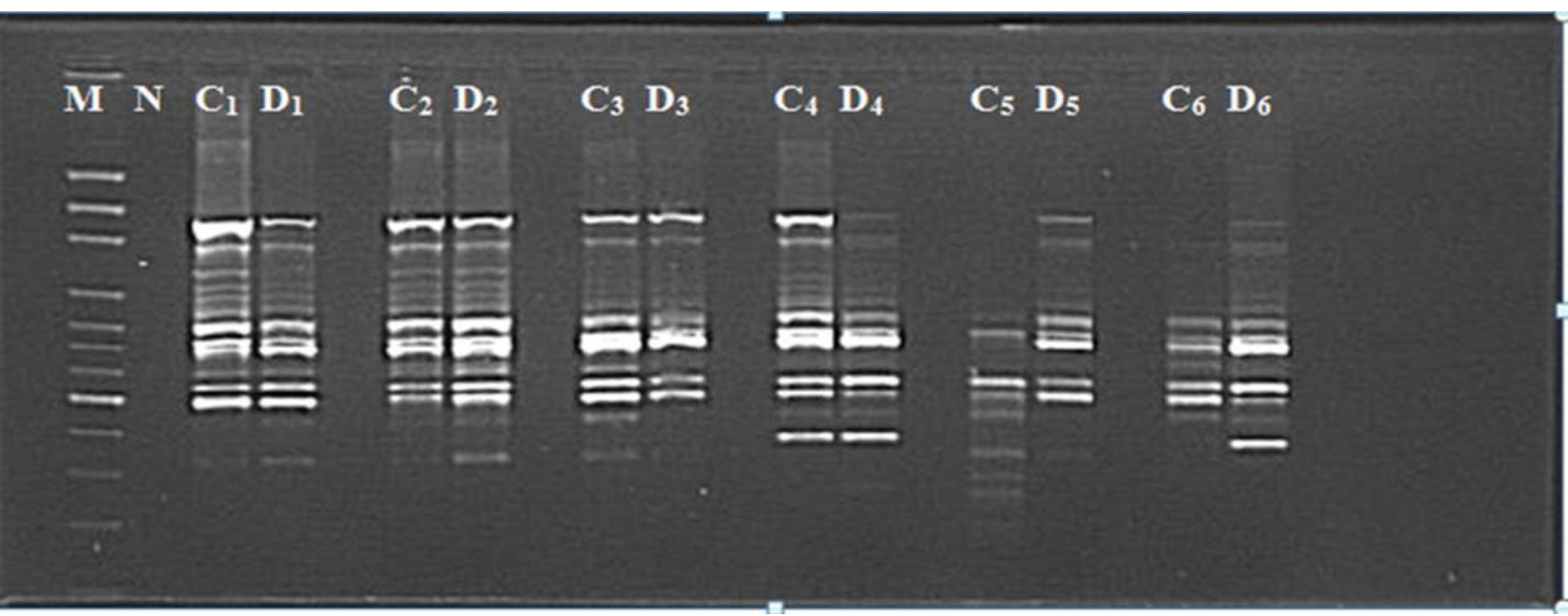

Figure 6: The image on agarose gel of amplification products are created by OPC 08 primer (M: marker, N: negative). 


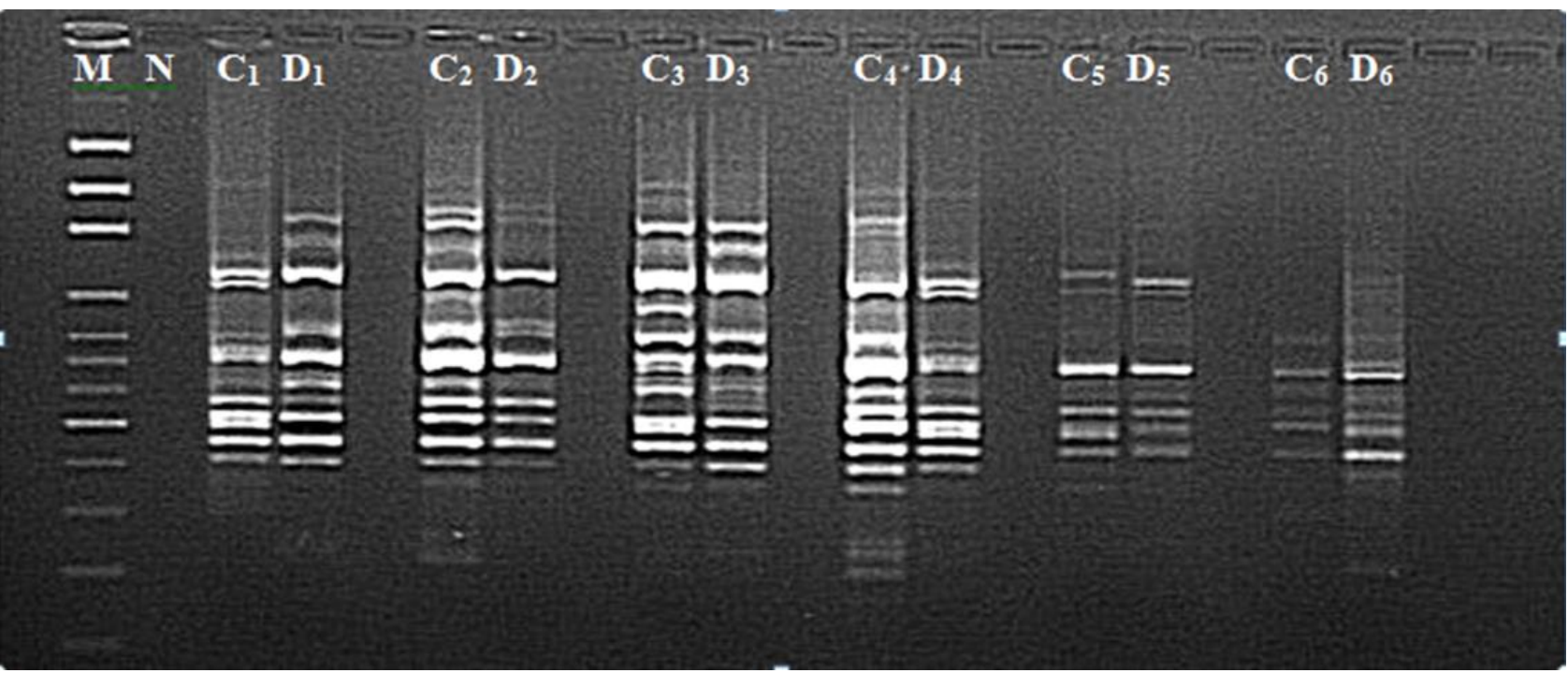

Figure 7: The image on agarose gel of amplification products are created by OPC 09 primer (M: marker, N: negative).

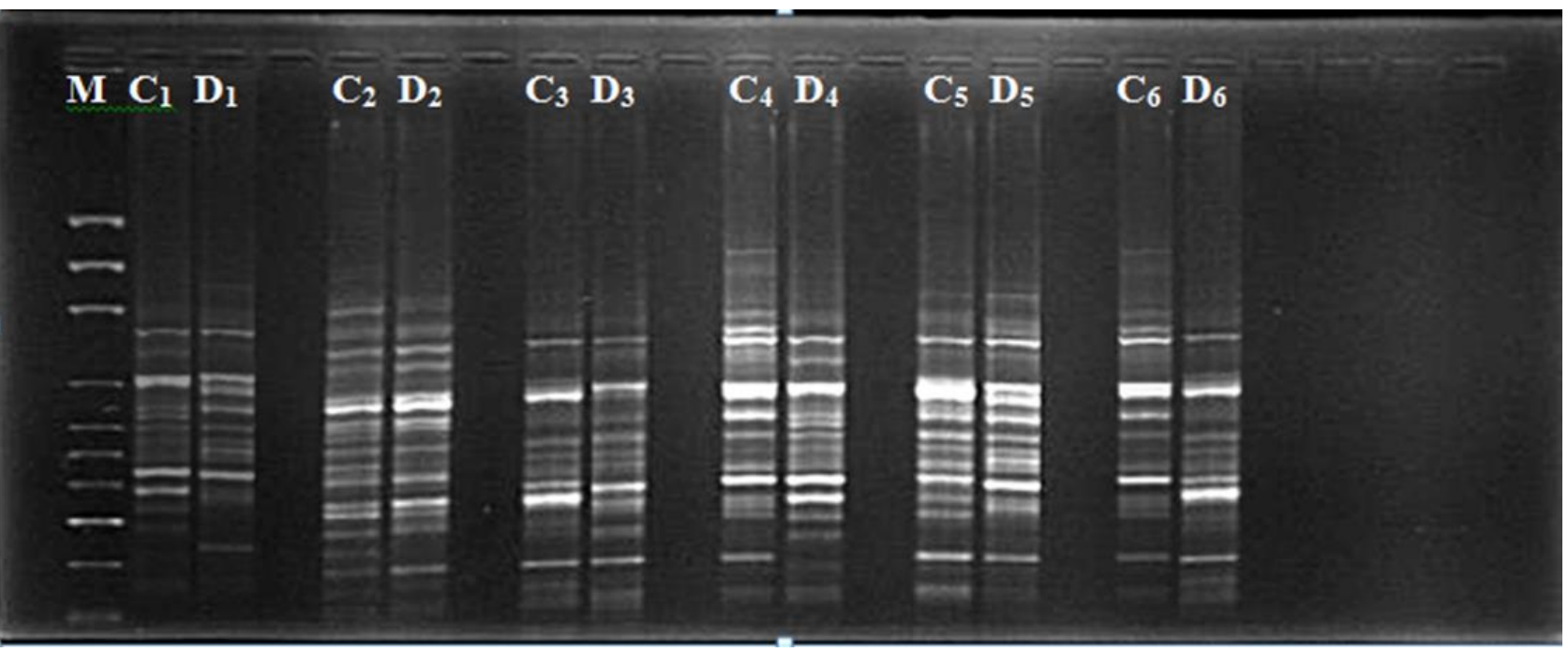

Figure 8: The image on agarose gel of amplification products are created by OPO 07 primer (M: marker).

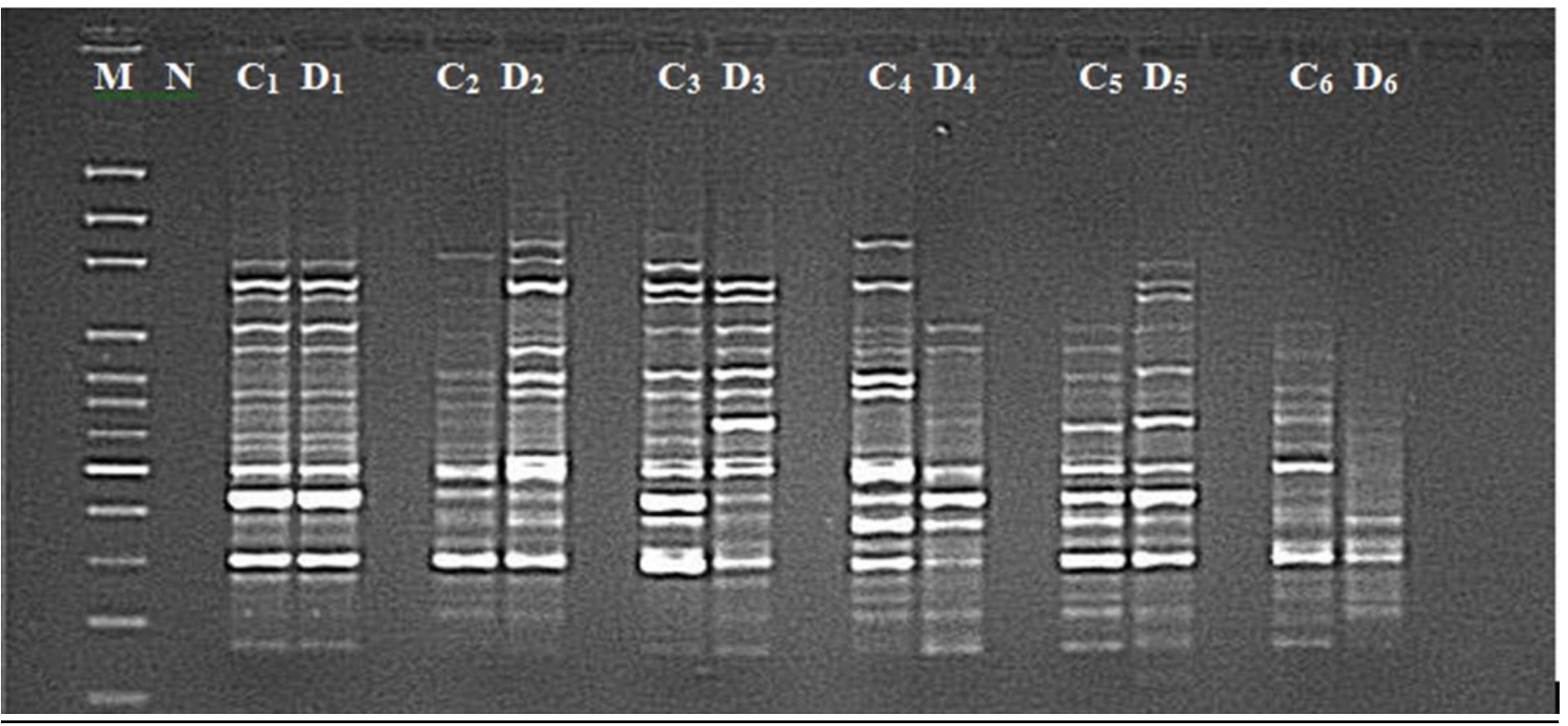

Figure 9: The image on agarose gel of amplification products are created by TUBE A08 primer (M: marker, N: negative). 


\section{References}

Algan, G., \& Büyükkartal, N.H. (1999). Tetraploid Çayırüçgülü (Trifolium pratense L.)'nde apomiktik gelişme. Turkish Journal of Agriculture and Forestry, 23, 519-525.

Aydın, S.Ö. (2004). RAPD (rastgele arttırılmış polimofik dna) belirleyicileri ve bitki sistematiği. DPÜ Fen Bilimleri Enstitüsü Dergisi, 6, 113-130.

Arslan, E. (2004). RAPD-PCR yöntemiyle Türkiye' deki Hyacinthella Schur (Liliaceae) türleri arasındaki polimorfizm ve filogenetik ilişkilerin belirlenmesi. Selçuk Üniversitesi Fen Edebiyat Fakültesi Fen Dergisi, 23, 2732.

Çölgeçen, H., \& Toker, M.C. (2008). Plant regeneration of natural tetraploid Trifolium pratense L. Biological Research, 41, 25-31.

Çölgeçen, H., Koca, U., \& Büyükkartal, H.N. (2011). Use of Red Clover (Trifolium pratense L.) seeds in Human Therapeutics. Nuts and Seeds in Health and Disease Provention, Chapter 115, 975-980.

Hossain, A., Konisho, K., Minami, M., \& Nemoto, K. (2003). Somaclonal variation of regenerated plants in chili pepper (Capsicum annuum L.). Euphytica, 130, 233-239.

Karataş, A., \& Ağaoğlu, Y.S. (2006). Güneydoğu Anadolu Bölgesi Üzüm Çesitlerine Ait DNA'ların Miktar ve Saflıkları Üzerine Bir Araştırma. Harran Üniversitesi Ziraat Fakültesi Dergisi, 10, 83-90.

Khan, S.Y., Ahmad, D., Adnan, M., \& Khan, M.A.K. (2014). The effect of somaclonal variation on salt tolerans and glycoalkaloid content of potato tubers. Australian Journal of Crop Science, 8(12), 1597-1606.

Kongkiatngam, P., Waterway, M.J., Coulman, B.E., \& Fortin, M.G. (1996). Genetic variation among cultivars of red clover (Trifolium pratense L.) detected by RAPD markers amplified from bulk genomic DNA. Euphytica, 89, 355-361.

Kumar, N.S. \& Gurusubramanian, G. (2011). Random amplified polymorphic DNA (RAPD) markers and its applications. Science Vision, 11(3), 116-124.

Lefort, F., Lally, M., Thompon, D., \& Douglas, G.C. (1998). Morphological traits microsatellite fingerprinting and genetic relatedness of a stand of elite Oaks. Silvae Genetica, 47, 5-6.

Filiz, E., \& Koç, İ. (2011). Bitki Biyoteknolojisinde Moleküler Markörler. Gaziasmanpaşa Üniversitesi, Ziraat Fakültesi Dergisi, 28(2), 207-214.

Patil, D.M., Sawardekar, S.V., Gokhale, N.B., Bhave, S.G., Sawant, S.S., Sawantdesai, S.A., Lipne, K., Sabale, S.N., \& Joshi, S.N. (2013). Genetic diversity analysis in cowpea by using RAPD markers. International Journal of Innovative Biotechnology and Biochemistry, 1, 15-23.

Polanco, C., \& Ruiz, M.L. (2002). AFLP analysis of somaclonal variation in Arabidopsis thaliana regenerated plants. Plant Science, 162, 817-824.

Sheidai, M., Aminpoor, H., Noormohammadi Z., \& Farahani, F. (2008). RAPD analysis of somaclonal variation in banana (Musa acuminate L.) cultivar Valery. Acta Biologica Szegediensis, 52(2), 307-311.

Soniya, E.V., Banerjee, N.S., \& Das, M.R. (2011). Genetic analysis of somaclonal variation among callus-derived plants of tomato. Current Science, 80, 1213-1215.

Williams, J.G.K., Kubelik, A.R., Livak, K.J., Rafalski, J.A., \& Tingey, S.V. (1990). DNA polymorphisms amplified by arbitrary primers are useful as genetics markers. Nucleic Acids Research, 18, 6531-6535. 